planiranja koju je zahvatio novi javni menadžment. Rezultati analize šest varijabli navode Nohrstedta na zaključak kako istraživanje neželjenih posljedica daje novo znanje za paradigme na nekoliko razina proučavanja.

Treća i završna cjelina posvećena je provjeri samih paradigmi na temelju raznolikih studija slučaja - od industrijske i obrazovne politike do energetske i politike zaštite okoliša. Završno poglavlje napisao je Martin B. Carstensen, $u$ kojem se daje kritički osvrt na koncept paradigmi, ali se naglašava i njegova važnost u novoj istraživačkoj agendi u domeni javnih politika. Kako sam Carstensen navodi, koncept paradigmi mora proći kroz još rasprava kako bi se ustvrdila važnost njihovih promjena, no prvi koraci u toj domeni već su napravljeni, što se vidi i u samom zborniku.

Zaključno, problem slabog isticanja i istraživanja samih paradigmi te njihovo nedovoljno integriranje $u$ postojeće teorije prikazano je na vješt način u ovom zborniku. Iako autori daju zanimljive preporuke kako koncept na bolji i sistematičniji način primijeniti, sam zbornik zbog navedene činjenice nailazi na stanovit problem konzistentnosti. Neovisno o tome, ako priloge zbornika gledamo kao razdvojene entitete, djelo daje širok teorijski i empirijski spektar gledišta na paradigme. Time se može reći da će zbornik biti relevantno štivo za studente, ali i profesore javnih politika, koji u žarištu svojega istraživačkog interesa stavljaju procese promjena i dinamike $\mathrm{u}$ kreiranju javnih politika, a nadamo se, $\mathrm{u}$ idućim radovima i istraživanjima, i koncept paradigmi koji je ovim zbornikom ponovno stavljen pod svjetla reflektora.

Željko Poljak https://doi.org/10.5559/di.26.2.10

\section{Chip Donohue FAMILY ENGAGEMENT IN THE DIGITAL AGE: Early Childhood Educators as Media Mentors}

Routledge, New York, 2017., 292 str.

Odgovarajuća primjena digitalnih medija i tehnoloških alata u učenju i razvoju djeteta, unutar njegovih primarnih okuženja (obitelj, odgojno-obrazovne ustanove), osim što će pridonijeti stvaranju zajedništva među njima, pospješivanju komunikacije, razmjeni informacija i osnaživanju roditeljskoga angažmana i znanja, pomoći će djetetu da se razvija, uči i snalazi u dvadeset prvom stoljeću. Upravo o tome govori knjiga "Obiteljski angažman $\mathrm{u}$ digitalnom dobu: odgojno-obrazovni stručnjaci u ranom obrazovanju kao medijski mentori", ističući ključnu ulogu i značenje medijskih mentora. Pritom se pojam odgojno-obrazovni stručnjak u knjizi odnosi na sve odrasle koji rade s djecom i obiteljima $\mathrm{u}$ ranom odgoju i obrazovanju, $u$ formalnom i neformalnom okruženju (odgajatelji, učitelji, pedagozi, psiholozi, knjižničari, socijalni radnici i slično). Pojam medijski mentor podrazumijeva svaku informiranu i osposobljenu osobu s kompetencijama za usmjeravanje, pružanje podrške i sigurno vođenje djece, kao i njihovih obitelji, kroz digitalno doba.

Urednik knjige, dr. sc. Chip Donohue, međunarodno je priznati stručnjak Eriksonova instituta u Chicagu (dekan je Centra za učenje na daljinu te direktor Centra za tehnologiju u ranom djetinjstvu na spomenutom institutu), čije je područje rada usmjereno prije svega na tehnologiju u ranom djetinjstvu. Knjiga, osim samog urednika, uključuje doprinose dvadeset i pet priznatih, utjecajnih i vodećih američkih autora na područjima ranoga obrazovanja, 
obiteljskog angažmana, tehnološke integracije, digitalnih medija i učenja. Njihovi su doprinosi $u$ knjizi organizirani unutar sedamnaest poglavlja, podijeljenih u tri cjeline. Autor nas uvodi u svaku cjelinu sažetim prikazom sadržaja svakoga poglavlja.

Prvu cjelinu pod nazivom "Tehnologija, mlađa djeca i obiteljski angažman" čini prvih pet poglavlja.

Prvo poglavlje prikazano je $\mathrm{u}$ obliku tri eseja. Prvim esejom "Zašto je bitno medijsko mentorstvo: jednakost u dvadeset prvom stoljeću" nastoji se istaknuti sve veća potreba za medijskim mentorima i važnost njihove uloge. Medijski mentor je osoba koja posjeduje specifična znanja za primjenu tehnologije i digitalnih medija u radu s djecom, kao i komunikaciji i usmjeravanju njihovih obitelji. Drugi esej "Tehnološki alati za obiteljski angažman: uloga različitosti" ističe kako odgojno-obrazovni stručnjaci trebaju imati na umu različitosti u djetetovim okruženjima. Stoga prilikom odabira i upotrebe odgovarajućih medija i tehnoloških alata u radu s djecom i poticanju obiteljskoga angažmana trebaju uzeti u obzir potrebe ciljane "publike". Treći esej "Zašto su obiteljski angažman, tehnologija i medijski mentori zaista važni", autor kojega je ujedno i sam urednik, naglašava činjenicu da je svakom djetetu, kao i roditelju, potreban medijski mentor, kako bi ih vodio u upotrebi medija, stvarao nove prilike za učenje, promovirao medijsku pismenost te otvarao nove mogućnosti obiteljskog angažmana.

Drugo poglavlje "Razvojno primjerena tehnološka integracija" iznosi ideju o tehnološkoj integraciji kao procesu ugradnje tehnologije, kao učinkovitog alata i sastavnoga dijela pedagoške prakse, što uključuje i razmišljanje o tehnologiji diljem kurikul(um)a i tijekom cijeloga dana, a ne samo tehnologiju kao odvojenu aktivnost. Pritom, razvojno primjerena integracija podrazumijeva učiteljske prakse koje osiguravaju djetetu podršku i instrukciju, koja će rezultirati optimalnim razvojem i učenjem (pružanjem prilika za kreativno i suradničko služenje tehnologijom za istraživanje, stvaranje i rješavanje problema).

Treće poglavlje "Promišljanja, a ne predmeti: ponovno promišljanje o angažmanu mlađe djece s tehnologijom i inovacijom" poziva na poticanje djetetova smislenog angažmana s tehnologijom. Primjerice: dublje razumijevanje i istraživanje tehnologije; vlastita stvaranja tehnologijom; od korisnika tehnologije prema kreatoru; upotreba tehnologije kao što se, primjerice, rabi plastelin, boja, papir, pijesak ...

Cetvrto poglavlje "Logiranje u obiteljski angažman u digitalno doba" govori o tome kako roditelji i obitelji, u poplavi digitalnih proizvoda koji mame djecu, traže savjete o tome gdje tražiti najbolje izvore za osnaživanje djetetova učenja od odgojno-obrazovnih stručnjaka, koji tada preuzimaju ulogu medijatora između novih tehnologija i obitelji.

Prva cjelina završava petim poglavljem "Uključene obitelji, moć nudget-a", u kojem autori naglašavaju potencijal tehnoloških alata (poruka, podsjetnika, aplikacija) u osiguravanju učinkovitih strategija za osnaživanje komunikacije i dijaloga obitelji i škole o djetetovu učenju i pružanju pomoći.

Druga cjelina pod naslovom "Tehnološki alati i tehnike za osnaživanje odgojno-obrazovnih stručnjaka i obitelji" obrađena je u okviru sljedećih pet poglavlja.

Šesto poglavlje "Što je činio gospodin Rogers: pristup Freda Rogersa roditeljskom angažmanu" osvrće se na život i djelo poznatoga američkog učitelja, autora pjesama, knjiga i voditelja poznate televizijske obrazovne, predškolske emisije za djecu "Mister Roger's Neighborhood". Osim što je svojim edukativnim emisijama nastojao poticati razvoj pozitivnih osobina djece i pomoći im u pravilnom razvoju, angažirao se i komunicirao s roditeljima 
koji su svakodnevno tražili njegove savjete $u$ vezi s roditeljstvom. Autor poglavlja čini poveznicu te ističe ulogu suvremenih odgojno-obrazovnih stručnjaka kao medijskih mentora u koje danas roditelji imaju povjerenja kao što su nekada imali u Freda Rogersa.

Sedmo poglavlje "Vođenje vremenske prognoze $\mathrm{u}$ digitalno doba" predstavlja metaforu i povezuje znanost o vremenu s djetetovom upotrebom medija te povećanje upotrebe tehnologije uspoređuje sa savršenom olujom. Kao što oluja može donijeti mnoge dobrobiti (kišu - voda je potrebna biljkama), ali i mnoge štete (previše kiše može uzrokovati poplave), tako i tehnologija i mediji mogu donijeti mnoge dobrobiti (razvijanje vještina rješavanja problema, kreativnost i kritičko promišljanje), ali i štete (pretjerana konzumacija, neprimjereni sadržaji). Prema tome, roditelji i odgojno-obrazovni stručnjaci trebaju se osloniti na svoje znanje o učenju i razvoju djeteta, psihologiju poučavanja i istraživati načine na koje mogu primjereno iskoristiti upotrebu tehnologije i medija s djecom.

Osmo poglavlje "Pomoć djeci i obiteljima u razvijanju zdravih navika korištenja medija" sugerira da, ako se rabi na razvojno primjerene načine is određenom namjerom, tehnologija može podržati djetetov razvoj i učenje. Pritom je važno da roditelji i odgojno-obrazovni stručnjaci formuliraju dobro promišljen, na informacijama utemeljen, plan upravljanja medijima, koji razmatra sedam ključnih područja: koje će medije djeca rabiti, kada, s kime, gdje, u koju svrhu, na koje načine te koliko će vremena posvetiti medijima.

Deveto poglavlje "Obiteljski angažman digitalnog doba: podrška roditeljima kao medijskim mentorima" uvodi nas $u$ načine na koje odgojno-obrazovni stručnjaci mogu pomoći roditeljima u snalaženju u ulozi medijskih mentora te ih uputiti kako modelirati odgovarajuću učinkovitu i pozitivnu upotrebu medija koja je sigurna, prihvatljiva, odgovorna i etična. Autorica pritom identificira šest ključnih faktora koje odgojno-obrazovne ustanove u ranom obrazovanju moraju uzeti u obzir u razvijanju pristupa koji će podržavati mentorsku klimu: tehnološko okruženje i dostupnost, tehnološke navike, stalno propitkivanje, evaluacija i samoevaluacija, ideologije o razvoju djeteta, kao i o tehnologiji te pružanje dobra uzora.

Deseto i završno poglavlje druge cjeline "Mediatricijski savjeti za suvremene medijske mentore" usmjerava pažnju na perspektivu Centra za medije i zdravlje djeteta u Bostonu, kojemu je cilj educirati i osnažiti djecu i one koji se o njima brinu za stvaranje i konzumiranje medija. U svrhu postizanja cilja, Centar je osigurao online savjetodavnu stranicu "Ask the Mediatrician", koja vodi roditelje, djecu i ostale edukatore kad im se obraćaju s raznim pitanjima i dvojbama u navigaciji digitalnim okruženjem. Na temelju rezultata mnogih istraživanja, predložene su praktične strategije, odnosno principi integracije novih medijskih tehnologija u učionice: odabrati ciljeve učenja, a zatim odabrati medijski alat; odabrati medije koji su dizajnirani za njegovanje djetetova učenja; odabrati medije koji ohrabruju interakciju.

Treća i završna cjelina "Inovativni pristupi tehnološki osnaženom obiteljskom angažmanu" obuhvaća zadnjih sedam poglavlja knjige.

Jedanaesto poglavlje "Selekcija digitalnih sustava koji poboljšavaju obiteljski angažman i komunikaciju" usredotočuje se na jasnu ilustraciju ključnih razlika među pojmovima komunikacija (koja obično podrazumijeva informiranje, jednostranu komunikaciju od škole/učitelja obiteljima), angažmana (koji obično podrazumijeva zajedničko razmišljanje, dvosmjerni angažman obitelji i učitelja te više obitelji 
međusobno) i uključenosti (koja obično podrazumijeva činjenje, s djecom i školskom zajednicom). Ponuđen je i vodič za odgojno-obrazovne stručnjake u odlučivanju kada i kako odabrati i primijeniti razne alate (društvene medije, aplikacije, internetske stranice, razne komunikacijske kanale) i strategije $u$ angažmanu i komunikaciji s roditeljima i obiteljima.

Dvanaesto poglavlje "Dijeljenje pristupa medijske pismenosti s roditeljima i obiteljima" donosi strategije i načine na koje odgojno-obrazovni stručnjaci u ranom obrazovanju mogu pomoći obiteljima $u$ razvijanju djetetove medijske pismenosti kroz nekoliko ključnih koraka: pristup medijima; znanje i svijest o medijima; analiza medijskih poruka (kritičko promišljanje o njima); evaluacija (donošenje informiranih, obrazloženih procjena o vrijednosti i pouzdanosti medijskih poruka) te stvaranje vlastitih medija i poruka (umjesto same konzumacije). Pritom valja obiteljima razjasniti razlike između medijskoga menadžmenta (primjerice, stvaranje pravila za uporabu medija i odabir medija) i razvijanja medijske pismenosti kod djeteta (kritičko razmišljanje o medijskim porukama, pronalaženje objašnjenja zašto je pojedini medij i/ili medijska poruka vrijedan, postavljanje pitanja o sadržajima medijskih poruka i pronalaženje vlastitih odgovora, refleksija na medije koje rabe i stvaraju).

"Strategije obiteljskoga angažmana za sve jezike i kulture" naslov je trinaestoga poglavlja, u kojem se autori usredotočuju na sve veću pojavu različitosti te naglašavaju važnu ulogu tehnologije u organizaciji i odgovoru na potrebe dvojezičnih obitelji. Za odgojno-obrazovne stručnjake, kao medijske mentore, autori nude primjere programa, inicijativa i izvora te prijed- log strategija za razmatranje prilikom angažiranja različitih obitelji.

U četrnaestom poglavlju "Univerzalni dizajn za učenje i pomoćne tehnologije: osiguravanje osjećaja pripadnosti svakome djetetu" autorica nastoji objasniti nove tehnološke alate koji će podržati inkluzivno okruženje, stvoriti dobrodošlicu za svako dijete i omogućiti mu osjećaj pripadnosti (podrazumijeva djecu s posebnim potrebama). U svrhu inkluzije, predstavlja univerzalni dizajn za učenje, koji je fleksibilan i dizajniran da stvara dobrobiti za sve, nudi načine učenja za različite osobe, ali su opći koncepti i konstrukcije dizajna iste za većinu. Autorica navodi višestruka sredstva prezentacije onoga što se uči, višestruke akcije i ekspresije (načini na koje djeca demonstriraju što znaju i mogu) te višestruke načine angažmana djece $u$ učenju, kao tri ključna principa univerzalnoga dizajna za učenje.

Petnaesto poglavlje "Dječji knjižničari kao medijski mentori" obrađuje koncept medijskoga mentorstva kao sastavni dio posla dječjih knjižničara. Budući da knjižnice mogu podržati djecu i obitelji u svim potrebama na područjima razvoja pismenosti, tradicionalnih i digitalnih, nova je uloga knjižničara, kao medijskih mentora, da ih podupiru u donošenju odluka i učinkovitoj upotrebi digitalnih medija $\mathrm{u}$ kontekstu knjižnice i izvan nje.

Urednik knjige autor je šesnaestoga poglavlja pod nazivom "Javni mediji i učenje kod kuće: angažiranje obitelji s transmedijima". Unutar poglavlja razmatra i okuplja studije slučaja i priče iz prakse fokusirane na inovativne prakse i razvoj novih tehnologija i medija, radi unapređenja spremnosti za školu i osnaživanje učenja kod kuće za djecu i obitelji. Prikazano je kako javni mediji mogu iskoristiti pristupe transmedija i digitalnih tehnologija kao učinkovitih alata za obiteljski angažman i učenje te prikaz pozitivnih ishoda za djecu.

Završno, sedamnaesto, poglavlje "Novi saveznici za digitalno doba: izgrađivanje politike i istraživačke infrastrukture 
za podržavanje medijskoga mentorstva" svojevrstan je zaključak knjige. Autori nastoje istaknuti i sažeti ključne koncepte i važne ideje izložene u knjizi. Predlažu niz akcija i strategija koje treba poduzeti u izgrađivanju učinkovite obrazovne politike posvećene medijskom mentorstvu, zagovaraju povezivanje istraživanja i prakse te poduzimanje koraka za pripremu kompetentnih medijskih mentora.

Knjiga, dakle, istražuje: značenje i važnost obiteljskog angažmana u digitalno doba; ulogu tehnologije kao snažnog alata $\mathrm{u}$ jačanju i angažiranju roditelja i djece u zajedničkom učenju, kao i u osnaživanju odnosa i komunikacije obitelji i odgojno-obrazovnih stručnjaka, te sve važniju ulogu odgojno-obrazovnih stručnjaka kao medijskih mentora za vodstvo djece i obitelji u digitalno doba. Ono što je čini specifičnom jest činjenica da autori $u$ svojim radovima, uz niz vlastitih iskustava i perspektiva, spoznaja relevantnih istraživanja i razvojnih teorija, studija slučaja i najboljih primjera i priča iz prakse, na kraju svakoga poglavlja nude najučinkovitije savjete i strategije za medijske mentore i/ili obiteljski angažman. Osim toga, uz opsežne popise referenci, nude niz materijala i internetskih izvora za dodatna istraživanja, usavršavanja i učenja o temama, ključnim konceptima i idejama predstavljenima u knjizi.

Na temelju navedenoga, mogli bismo reći da je knjiga vrijedan doprinos za sve stručnjake (i studente) u odgoju i obrazovanju kojima je potrebno vodstvo, usavršavanje i stjecanje novih kompetencija kako bi se snašli u ulozi medijskih mentora. Naime, ova im knjiga može poslužiti kao svojevrstan praktični vodič za primjenu i primjerenu upotrebu nove teh- nologije i digitalnih medija u pedagoškoj praksi; stvaranje novih prilika za učenje i razvoj djeteta te kao alat za komunikaciju s tehnologijom i angažiranje obitelji. Naime, sadržaj i pristup knjige pomoći će im u razvoju znanja, iskustva i sposobnosti kako bi dosegli odgovarajuću razinu digitalne kompetencije, potrebne da bi postali učinkoviti medijski mentori djeci i obiteljima digitalnoga doba.

Katarina Sušanj Gregorović

\section{https://doi.org/10.5559/di.26.2.11 \\ Brigid Freeman, Simon Marginson i Russell Tytler THE AGE OF STEM Educational policy and practice across the world in Science, Technology, Engineering and Mathematics}

Routledge, Taylor \& Francis Group, Abingdon, Engleska, 2015., 304. str.

Knjiga Doba STEM-a: Obrazovne politike $i$ prakse diljem svijeta $u$ znanosti, tehnologiji, inženjerstou i matematici (The Age of STEM: Educational policy and practice across the world in Science, Technology, Engineering and Mathematics) objavljena je $u$ izdanju izdavačke kuće Routledge, Taylor \& Francis Group 2015. godine. Urednici i autori knjige, koja sadrži 304 stranice na engleskom jeziku, jesu Brigid Freeman, Simon Marginson i Russell Tytler. Uz navedene autore, $\mathrm{u}$ knjizi se pojavljuju i ostali autori koji donose tekstove o STEM području iz svojih zemalja ili regija. Uz sadržaj, popis grafikona, popis tablica, liste suradnika, predgovora i zahvale, koji se nalaze na počet$\mathrm{ku}$, na samom kraju knjiga sadrži kazalo pojmova te popis literature na kraju svakoga poglavlja. Kroz 17 poglavlja autori u 